\title{
The Value of Doubt: Humanities-Based Literacy in Management Education
}

\author{
Ulrike Landfester $^{1} \cdot$ Jörg Metelmann ${ }^{1}$
}

Received: 9 August 2019 / Accepted: 27 October 2020 / Published online: 6 November 2020

(C) The Author(s) 2020

\begin{abstract}
Our paper addresses the question of what exactly the contribution of the humanities to management education could or should be, suggesting the concept of Literacy as both this contribution's goal and method. Though there seems to emerge a consensus in the debate about the future of management education that the humanities should be involved with shaping it, some misconceptions about the humanities obscure the understanding of the why and how of it, most notably as to the manner in which they are to provide for ethical values. Our paper in a first step endeavours to clear those misconceptions up drawing on some historical aspects of their development. It then proceeds to introducing the concept of Literacy and, based on it, the teaching framework of Critical Management Literacy (CML) we designed to operationalize the concept towards management students` needs. Our leading hypothesis is that the contribution of the humanities should focus on the cultivation of the capacity for epistemological doubt in order to prepare students for the complexity and indeterminacy of reality, thus at the same time laying the groundwork for ethical reflectivity.
\end{abstract}

Keywords Humanities · Management education - Ethical values - Epistemological doubt $\cdot$ Critical thinking · Literacy

\section{Introduction}

The call for an integration of the humanities - in the U.S. more often known as the liberal arts into management education has been getting louder over several decades. In 1994 Donaldson and Freeman in their preface to Business as a Humanity stipulated clearly "that we must add

Jörg Metelmann

joerg.metelmann@unisg.ch

Ulrike Landfester

ulrike.landfester@unisg.ch

1 School of Humanities and Social Sciences, University of St.Gallen, Müller-Friedberg-Strasse 6-8, 9000, St.Gallen, Switzerland 
the humanities to the repertoire of business education if managers and employers are to understand the world they currently face" (p. vii). As the Carnegie report Rethinking Undergraduate Business Education. Liberal Learning for the Profession (Colby et al. 2011) which examines the use U.S. business schools made of the liberal arts, and the complementing report on European business schools (Landfester \& Metelmann 2019) have shown, since then a rising number of business schools have begun to move towards integrating the humanities. Both reports equally show, however, that though great expectations are launched at the humanities, even at those avantgarde schools there is little systematic knowledge to be found as to what precisely the humanities are expected to deliver and how to go about it, both on the side of the humanities and on that of management educators. Thus, the concern voiced by Zald, who in 1996 already declared "the turn to the humanities to be almost inevitable" (p. 260), that " $<$ t>he opening to the humanities has occurred not according to some grand plan but as particular scholarly discourses" and was therefore yet "incomplete" (p. 253), is still valid today.

Our paper argues that what the humanities have to offer to management education is, in the terms of our title's first part, the value of doubt, more specifically the value of epistemological doubt. Epistemological doubt is the capacity to constantly question the assumptions and preconceptions underlying bodies of knowledge - like, for example, the body of disciplinary knowledge handed down in management education - as to the validity of their relationship with reality. As such, it is the precondition of the ability to judge the interpretative choices among them, though not exclusively, moral choices - made by the individual upon encountering the irreducible indeterminacy of meaning inherent to reality (Gadamer 1989; Figal 1991). In other words, the value of epistemological doubt as practised and taught by the humanities lies not in the production of prescriptive knowledge about moral or any other values. Rather, the "morally vital dispositions of liberal education" (Nesteruk, 2012 p. 118) enable the individual's capacity for building and maintaining such values by permanently reflecting on the implicit frameworks which shape his or her response to a world that is increasingly characterized by Volatility, Uncertainty, Complexity and Ambiguity, as the famous Harvard VUCA acronym has it.

The value of epistemological doubt for the mature use of reason, as we will show in the first of our paper's three sections, led Wilhelm von Humboldt to establish the Berlin prototype of the modern university with the humanities at its core. Because of his expertise in this area, he considered them the mainstay of his vision of Bildung, charging them to develop and maintain a style of reasoning which would bind all academic scholarship together through its shared use. As this use is exploratory and non-teleological by nature and more suited to examine a phenomenon's intrinsic value than to directly contribute to the efficiency-driven value chain modern economic thinking mostly favours, it became subsequently marginalized by the academia towards the end of the nineteenth century. Recently, though, it has been welcomed back most notably by management and organizational studies especially in the field of narratological analysis (Czarniawska et al., 1994; Czarniawska, 1997; Hjort and Steyaert, 2004; Gagliardi and Czarniawska, 2006; cf. Steyaert et al. 2016). To (re-)introduce epistemological doubt into the economist narrative which still frames much of the contemporary understanding of management (cf. Krugman, 1998; Lovins, 2016; Pirson, 2020) narratological analysis in organization and management studies (Rhodes and Brown, 2005; Beigi et al. 2019) is certainly an important tool to employ, seeing that the capacity for "storytelling" is part of the human condition (Gottschall, 2012). It is, though, but one of the areas of the humanities' expertise to be mined for the benefit of management education. Arguing that for both historical and systematic reasons the humanities are in a unique position to help with correcting the 
damage incurred by, as Ghoshal (2005) put it, "Bad Management Theories <...> Destroying Good Management Practices" (p. 75), we want to showcase the concept of literacy as a much broader approach to the value added by the humanities to academia in general, but to business thinking and management education in particular.

To showcase what we perceive of as the humanities ' contribution to the "Human Turn" in management studies evoked by Raffnsoe (2016; forthcoming 2021), we present a concept of what we term Literacy in the third and fourth sections of our paper. The third section is dedicated to outlining Literacy as a conceptual framework. We developed this conceptual framework from the term Cultural Literacy as introduced by Hirsch in 1987 who argued in favour of a shared body of cultural knowledge consisting of pieces of information like names, historical events, famous artwork and technological innovations, to name but a few.

With reference to Clifford Geertz (1973) and Richard Rorty (1979), however, we go one step further than Hirsch by focusing on the process of cultural interpretation itself - as Rorty says, "anthropologizing the West." To this end, we make use of the key concepts that the European Science Foundation has identified as the contribution of the humanities: textuality, rhetoricity, historicity and fictionality. In other words, the bodies of knowledge shared by literates in Hirsch's sense are shaped by assumptions and preconceptions about reality which feed back into the interpretative choices that are made by their users. Literacy in our sense of the term therefore is the capacity to recognize those bodies of knowledge as interpretative meta-systems and, even more important, to take the assumptions and preconceptions about reality they are based on into consideration when making such choices.

In the fourth part we then show how the epistemic doubt can be operationalized. Starting from Deidre McCloskey's (1983, 1985, 1990, 2001) insistence on the rhetoric of economic facts and theories, we draw a bow to the Western alphabetical writing system, which, in contrast to pictographic alphabets, for example, is fed by an inconclusive openness and indissoluble ambiguity. We concretize the reflection on this basis of not only European thinking in four partial literacies, which together form a form of Critical Management Literacy: Conceptual Management Literacy, Cultural Literacy, Social Literacy and Interactional Literacy. We conclude this fourth part with practical experience from an MA course on "Strategy as Cultural practice".

As our concluding remarks will outline, there is certainly room for improvement on details, methodological and otherwise, but our findings so far suggest that in terms of value-building introducing epistemological doubt into management education appears to work.

\section{Great Expectations: A Short Historical Note on the Humanities`Morality}

Great Expectations is the title of a novel published by Charles Dickens in 1860-61. Its convoluted storyline is classical Dickens: Pip, the protagonist, expects his rich benefactress to make him her heir and marry him to her beautiful but cold-hearted daughter Estella whom he is in love with. He is disappointed by his benefactress apprenticing him to a smith and marrying her daughter to another man, then anonymously receives a huge fortune he believes to come from her, only to find out that the fortune was given to him by a criminal whom he had been kind to as a child. This convict is finally hanged, so that Pip loses his fortune again, but reconnects by chance with the now-widowed Estella who is mellowed by her dead husband's mistreatment of her and walks off the story-telling scene hand in hand with the blissful Pip. As always, Dickens succeeds in leading the reader's expectations of what the novel really is about from one blind alley into the next, and even the reunion of Pip and Estella 
is full of double meanings: Money, the dedicated critic of capitalism Dickens concludes, is in the end not what makes Pip happy, instead having brought much suffering for all parties concerned - but the happy end would certainly not have come to pass without all this suffering and thus without the huge fortunes involved.

The reason for us referring to Dickens' novel here is that the story of the expectations currently launched at the humanities has a similar feel to its plot, since it unfolds in a field of tension marked out by two, on the face of it, antagonistically conflicting challenges. On the one hand, the humanities are to "augment the competitiveness of organizations in the next century" by mining "the relevance of a liberal education to future career success" (Bobko and Tejeda, 2000 pp. 1-2); they are to help deal with the challenges that "globality, blurring boundaries, and messy real-world conditions" impose on contemporary businesses (Waddock and Lozano, 2013 p. 267) and thus improve on "a range of managerial capabilities from creative, critical thinking to integrative problem framing and solving that would enhance the basic knowledge of business and analytic skills" (Thomas et al. 2014 p. 11). Clearly rooted in the economist narrative's focus on efficiency maximization, the usefulness of the humanities is measured in terms of the graduates' professional success, thus mirroring the way in which today's "marketized education system" depends on "a presumed link between educational choice and the (more or less) guaranteed transition into the labour market" in order to sell "the exchange value of a specific education" to its student customers (Perriton and Singh, 2016 p. 82).

At the same time, the humanities are called upon for a "Moral Transformation of Business Education" (Nesteruk, 2012) to restore humanity in the most emphatic meaning of the word to its rightful place which is currently usurped by economic thinking "as the core value of political discourse" (Hendry, 2006 p. 23). Since business schools, as Ghoshal (2005) claims, by sticking to this narrative and thus "propagating ideologically inspired amoral theories $<\ldots>$ have actively freed their students from any sense of moral responsibility" (p. 76), it is hoped that the humanities might provide for" a moral rearmament against the harsh instrumentality that serves outright greed" (Guillet de Monthoux, 2015 p. 1). Such calls to humanitiesproduced moral arms against "outright greed" seem, on the face of it, to suggest that there is an intrinsic morality to the humanities which is needed to counter an equally intrinsic lack of morality in the economist narrative.

Yet, similar to the plot of Dickens' novel, the story of the expectations launched at the humanities is far more complex than that, hinting to an intricate balance to be found in the end. As research arguing for an inclusion of literary narratives in management education shows, beneath the faint remnants of the belief in the humanities' intrinsic morality there is a growing awareness that it is in fact their guiding students to the inevitability of interpretative choices and their taking responsibility for them - through literature which lies at the bottom of the humanities providing for ethical values (Czarniawska et al., 1994; Westerman and Westerman, 2009; Younkins, 2014; Shepard et al., 1997). As Czarniawska et al. (1994) pointed out in the foreword to Good Novels - Better Management, novels, especially those written during the period of nineteenth century Realism represented, among others, by Dickens, can not only supplement the corpus of reliable case studies used in management education; rather, and possibly even more important, students who are used to regarding texts as mere carriers of information to be harvested are guided to treat them as artefacts in their own right, which prevents them from developing "into humanoid word processors without judgmental skills" (p. 6). Along similar lines, Michaelson (2016) referred his findings on the use of novels in management education to the Carnegie report's call for more interdisciplinarity (p. 591), 
arguing that great novels "elicit empathy for nonfinancial value" and, being "written primarily as intrinsically valuable art works that make life worth living" and "manifesting the value of art for art's sake", they can be "instrumentally valuable at helping business ethics educators to develop better persons and more responsible professionals" (Michaelson, 2016 pp. 602-603) by confronting them with the indeterminacy of meaning inherent to aesthetic experiences.

The impression of moral essentialism which still sometimes cling to the humanities` general image is due to a historical simplification which foreshortened their role in the development of ethical values. In its more explicit manifestation, this role appeared only towards the end of the eighteenth century by the German Enlightenment movement. An early strand leading up to it does go back as far Roman antiquity when studying the artes liberales "implied both civic commitment and a striving for personal virtue or excellence" (Arenas, 2006 p. 115) and as such was considered the prerequisite of occupying any given political position. When the first universities were founded in Europe in the middle ages, this focus broadened towards mandating the artes liberales to provide for a shared body of knowledge for future professionals in the fields of theology, medicine and the law. Under the influence of the ideas and values of the Enlightenment, this role to a large extent remained with the artes liberales when Humboldt founded the Berlin prototype of the modern university in 1810. Now, though, it was to be played under explicit orders to create not only a shared body of knowledge but one of intrinsic morality.

In his vision of the university founded on the behest of the Prussian king Frederick William III., Humboldt decisively subscribed to the arguments laid out by Kant in his three Critiques, namely, that the use of reason for applying epistemological doubt was the basis for morality and that, moreover, such use was the indisputable right as well as the duty of human beings in their quest for truth, the latter argument culminating in Kant's highly influential essay What is Enlightenment? (Kant, 1784; cf. Pinker, 2018). On those grounds, Humboldt established the Berlin university with a view to, as Readings (1996) put it, "the ennoblement of character" (p. 65 ) of its students. The memorandum which accompanied his application for funding for the new university to the Prussian king, dated July 24, 1809, explicitly stated "that institutions of higher scientific education are the summit where everything converges which is done for a nation's moral culture rests on them being ordained to work on science in its deepest and widest sense, and to deliver them as a material which is $\langle\ldots\rangle$ in itself purposive for the application of mental and moral education" (Humboldt, 1990 / 1809 p. 273). For Humboldt, the humanities - then mostly philosophy and the philologies - were the main procurators of the use of reason he envisioned as the intellectual core of the university and as such in charge of its morality, which is how they came to be associated with the latter until today. However, it was not the assumption, nor even the request, that they produced normative orientational knowledge prescribing moral and condemning immoral action which made this association grow from the concept of the medieval studium generale. Instead, it was the method of explorative reasoning which constituted their claim to morality, which the Carnegie report encoded as the capacity for and practice of "Analytical Thinking, Multiple Framing, and the Reflexive Exploration of Meaning" (Colby et al., 2011 p. 9). The goal of teaching this method was that "the subject learns the rules of thought, not a content of positive knowledge, so that thought and knowledge acquisition become a freely autonomous activity, part of the subject. <...> What is thus taught is not facts but critique - the formal art of the use of mental power, the process of judgment." (Readings, 1996 p. 67).

When the natural sciences` relentless positivism gained methodological supremacy in the academic disciplines infighting for the claim to the most valid type of knowledge production 
towards the end of the nineteenth century - the same time when business schools first entered the academia, modelling their burgeoning discipline on the natural sciences in their quest for academic credibility (cf. Clegg et al., 2003; Ghoshal, 2005) - the humanities ' methodology slowly lost its hold on education. Openly and stubbornly reneging on adjustment to the increasingly powerful myth of Homo sapiens as Economic Man, they found themselves on the wrong side of the gap which had begun to divide scholarship into what Snow (2001/ 1959) was later to call "two cultures." By then, their image as the procurators of morality was starting to become more of a liability than the asset it had been, as it was simplified into mere normative self-righteousness, the importance and role of epistemological doubt in the enabling of moral practices fading from memory, which resulted in a still-ongoing "standoff between liberal humanism and utilitarianism" that has "shaped academics, disciplines and institutions" (Parker, 2016 p. 497). At the same time, higher education as a whole began to turn to the logics of utilitarianism which forced universities "to think about their own activities in terms of markets and products", resulting, among other effects like cutting down on the funding for the humanities, in " $<\mathrm{t}>$ he removal of the critical warrant in management education" (Perriton and Singh, 2016 pp. 81-82).

It is this development which has led to the perceived lack of ethical awareness in management education, which in fact is rather the lack of epistemological doubt. As Dewey (1929) put it, " $<$ a $>$ moral law $<\ldots>$ is not something to swear by and stick to at all hazards; it is a formula of the way to respond when specified conditions present themselves $\langle\ldots$. . Its claim to authority rests finally upon the imperativeness of the situation that has to be dealt with, not upon its own intrinsic nature." (p. 278) It is thus not a normative approach but the capacity for epistemological doubt which allows for both the wisdom and the pragmatism (cf. Statler and Salovaana, 2016) to assess a situation, explore its implications and choose appropriate responses. Applied to the assumption of an antagonism between morality and economic thinking which has tinted much of the criticism launched at business schools after the recent financial crises, epistemological doubt might, for instance, suggests that this assumption is one of the side effects of said crises: "Rather than being seen as a systemic issue within capitalism, the crises have been attributed to the absence of ethical or moral behaviour of individuals" (Perriton and Singh, 2016 p. 83), creating a convenient outlet for righteous indignation in order to avoid a much more difficult issue. At the same time, " $<w>$ hat is obscured in a purely negative moral interpretation of 'business' is perhaps its most important character", because, Costea and Amiridis (2016) claim, "since the dawn of modernity it has $<\ldots>$ been the domain claimed by the modern subject for the expression of its freedom" (p. 515).

To sum up, rewriting - or rejecting - the economist narrative in management education needs to carefully explore those aspects in order to choose responses which really make a difference instead of replicating old arguments in new guises. As showcased by the conflicts that shape Pip and Estella's story in Dickens' novel (cf. John 2003), simplistic reductions mislead both readers of the economist and those of the moralist narrative into believing that reality adheres to binary logics, while in fact it requires situated syntheses of multipolar experiences and accordingly multipolar grounds for interpretative choices like those that finally bring Pip and Estella to their happy end. What the humanities can contribute to a possible happy end of the story of their integration into management education is to lay or at least broaden the foundations for such syntheses in order to retrieve what Perriton and Singh (2016) call the "critical warrant in management education" (p. 81), which is where the concept of literacy comes in. 


\section{In Quest of Shared Knowledge: The Concept of Literacy}

The meaning which we ascribe to the term "literacy" in our conceptual framework is situated on a tertiary level, that is, it builds on two levels of meaning preceding it both historically and systematically. On the most basic level, being derived from the Latin word littera for the written letter representing one of the 26 phonemes which constitute the alphabet, the term in Roman antiquity denoted the capacity of using the alphabetic writing system, while today it is also being used in connection with other writing systems like Chinese script. On the second level, the term has acquired another dimension of meaning which was similarly prefigured by Roman antiquity's use of the plural litterae for written texts as such, usually associated with the whole available corpus of literary or scholarly writings constituting Roman culture's repository of available knowledge. On that level, the term encompasses all types of processing, storing and distributing information encoded in conventionalized patterns. While the emergence of research on literacy with the seminal work of Eric Havelock (1976) still remained largely bound to the basic understanding of literacy as the capacity to read and write, taking the concept to this level of meaning goes back to what Eric D. Hirsch introduced as "cultural literacy" in 1987, which is the point of departure from which we built our conceptual framework.

Hirsch Jr. (1987) coined the term of "cultural literacy" to describe what, in his opinion, was missing in the then contemporary U.S. American educational system. According to him, Literacy is the capacity to access and navigate "the network of information all competent readers possess" (p. 2), a body of knowledge shared by all members of a community - in his case the American nation - which enables them to communicate efficiently and transparently. To define this body of knowledge practically, he added a list of the pieces of information making up this network which in his book's revised version of 1988 fills 63 double-columned pages, running from "Aaron, Hank" (p. 152) to "Zurich" (p. 215) and encompassing pretty much all possible manifestations of culture including artwork and literature, technical and political acronyms, places and buildings, proverbs and the names of diseases. Exploring this train of thought further, Kalantzis and Cope (2012) in their study Literacies distinguish between two "multiliteracies" (p. 2), one, what they call "modal" multiliteracy, referring to the first level in its focus on the different types of codes used to communicate - written, visual, spatial, tactile, gestural, audio, and oral signification -, the other, "contextual" multiliteracy, broadening their concept to include organizational structures like community settings, social roles, identity layouts and interpersonal relations (ibid. p. 49). The argument underpinning this approach is that "communication increasingly requires that learners are able to figure out differences in patterns of meaning from one context to another and communicate across these differences as their lives require" (ibid. p. 1), an argument which is already faintly visible but still remained implicit in Hirsch's concept.

Hirsch's (1987) broad understanding of culture and his notion that sharing a body of cultural knowledge is elementary for the functioning of any given community, profiled further by Kalantzis and Cope's (2012) elaborating on it, lies at the bottom of our own concept of Literacy. That said, our concept of Literacy takes this understanding another step further, as it shifts its focus from the mere accumulation of information towards the manner in which the items which make up the shared body of knowledge are linked in terms of correlative meanings. Our approach thus subscribes to the ethnological one employed, among others, by Clifford Geertz' (1973) collection of essays The Interpretation of Cultures. Based on Max Weber's belief "that man is an animal suspended in webs of significance he himself has spun", 
Geertz (1973) takes "culture to be those webs, and the analysis of it therefore not being an experimental science in search of law but an interpretive one in search of meaning" (p. 311). Fundamentally questioning Western scholars' traditional understanding of knowledge, this approach argues that, as Rorty (1979) put it, their "desire for a theory of knowledge is a desire for constraint, a desire to find 'foundations' to which one might cling, frameworks beyond which one must not stray, objects which impose themselves, representations which cannot be gainsaid" (p. 315). In other words, the effect of this "desire for constraint" is to crowd out epistemological doubt, ontologizing the assumptions and preconceptions underlying its thrust so as to invest them with the validity of laws of nature. To get at those assumptions and preconceptions to examine their claim to validity, though, needs a categorically different approach: "We need to anthropologize the West: show how exotic its constitution of reality has been; emphasize those domains most taken for granted as universal (this includes epistemology and economics); make them seem as historically peculiar as possible; show how their claims to truth are linked to social practices and have hence become effective forces in the social world." (Rabinow 1986 p. 241).

Possibly the most influential one of those practices is the use of the phonetic alphabetic writing system which emerged in Greece from the consonantal alphabet brought to the Greek mainland by Phoenician traders at the beginning of the first millennium BC. The phonetic alphabet has several functional aspects which, being historically peculiar indeed, allow to anthropologize the West by tracing their influence on the concepts which make up its cultural identity. One such functional aspect, and probably the best known one, is the sheer simplicity of a system which consists of 26 letters including five vowels, combinations of which allow to note down units of information in a manner that they can be read even by persons who do not know the language in which the words are written. Though this simplicity, which made it comparatively easy to learn and apply and thus was crucial for its spreading quickly from the Mediterranean to the rest of Europe, is certainly one of the reasons why the phonetic alphabet became "a writing which changed the world" (Powell, 2012 p. 227), it is by no means the only one. Alphabetic writing today is recognized to be not only a useful tool for processing, storing and distributing information but to exert an influence on the content laid down in it which "suggests that the development of the Western scientific and philosophical traditions might reflect a way of experiencing ideas that is the product of the Greek alphabetic system" (Jones and Aoki, 1988 p. 318), neuroscientific research on gene-culture-coevolution even arguing that in the long run its use impacts on the genetic formation of the human brain (Lumsden, 1988).

Along those lines, our concept of literacy anthropologizes what Geertz (1973) describes as the "webs of significance" generated by human cultures by examining cultural technologies as to the impact their functional aspects exert on the patterns of interpretative choices they enable, require, restrict or even exclude. Our use of the term literacy refers to the alphabetic writing system as one of the and perhaps even the most basic of those technologies, holding that to a certain extent any Western cultural practices and the concepts they produce and promote rest on the use of this system, which is why we deem the capacity for quite literally reading them essential for dealing with the indeterminacy of meaning inherent to reality. As such, our concept chimes in with what Tsoukas (2005) terms "poetic praxeology":

"Knowledge is the outcome of an active knower who has a certain biological structure, follows certain historically shaped cognitive practices, and is rooted within a consensual domain and sociocultural practice. A poetic praxeology sees the practitioner as an active being who, while inevitably shaped by the sociocultural practices in which he/she is rooted, necessarily shapes them in turn by undertaking action that is relatively opaque in its 
consequences and unclear in its motives and desires, unreflective and situated in its mode of operation, but inherently capable of self-observation and reflexivity, thus susceptible to chronic change. $\langle\ldots\rangle$ A poetic praxeology acknowledges the complicated motives of human intentionality, allows for chance events, influences, and feedback loops, and accepts the inescapable contextuality and temporality of all human action." (Tsoukas, 2005 p. 5).

To establish the elements of such a praxeology, our concept of literacy draws heavily on the science policy paper Cultural Literacy in Contemporary Europe published by the European Science Foundation (ESF) in 2013. It was authored by a working group consisting of members of the ESF's Standing Committee for the Humanities $(\mathrm{SCH})$ charged with spelling out the core characteristics of humanities-produced knowledge. The paper identifies the epistemological understanding of the mechanisms of social interaction through cultural artefacts as the humanities' main area of expertise, focusing on four major fields, that is, the expertise as to textuality, rhetoricity, historicity and fictionality. It argues that any artefact, material or immaterial, is textual in nature in that it is built along the lines of a logic which may have little to do with the subject it deals with but everything with the context it is used in; that any artefact uses rhetorical devices to manipulate its recipient according to its underlying norms and frameworks of value; that any artefact has a historical dimension impacting on the meaning it transports, and finally, that any such meaning has fictional components, as each communication through artefacts is as such intrinsically fictional in structure. On top of this structural fictionality, though, additional fictional elements can be added to manipulate readers with polemical intent, which makes distinguishing one from the other an essential competence (European Science Foundation (ESF), 2013 p. 6).

Literacy, as we understand it, thus premises both the basic meaning of the term as describing the technical capacity to read and write and the broader meaning developed by Hirsch Jr. (1987) describing the capacity to access and navigate the shared body of knowledge which represents cultural identity or, as Kalantzis and Cope (2012) have it, cultural identities in the plural. Building on this, our concept stipulates a shared body of knowledge about the textual, historical, rhetorical and fictional components of encoding which goes beyond both its technical and its organizational aspects in that it includes the awareness of the latter's conceptual influence. Literacy in our sense of the term thus becomes the capacity to distinguish those components with a view to assessing their impact on the information conveyed through them by means of epistemological doubt, the operationalization of which, especially for management studies, we will endeavour to explain in our paper's next and final section.

\section{The Value of Literacy: Operationalizing Epistemological Doubt}

Advocated by Kant (1784) as being both the logical consequence of rational thought and as such the precondition of moral judgment, and in that role established by Humboldt as the overall core mode of the modern university's use of reason, epistemological doubt is the capacity to question the preconceptions and assumptions about reality which underlie interpretative choices made in response to reality's indeterminacy of meaning. Research on making such choices in behavioural economics has shown that most people "do not understand how they actually make decisions" (Bazerman and Moore, 2009 p. 5), so that "the vast majority of unethical behaviours occur without the actors` conscious decision to behave unethically" (ibid. p. 123), , habitually following conventionalized patterns of interpretation rather than questioning their validity as to its premises. Epistemological doubt counteracts such habits 
of making sense by establishing such questioning as an integral part of the decision process in order to achieve intellectual and with it ethical clarity in judgment.

However simple this may sound, in the realm of the economic narrative this mode appears to meet some determined resistance, as illustrated by some of the reactions to McCloskey's $(1983,1985,1990,2001)$ spirited attempt to lay out the extent to which economists employ rhetorical devices like metaphors to explain their findings to their students (cf. also Morgan, 1986; Oswick and Grant, 2015), their peer group and the clientele potentially paying for their expertise. McCloskey's work in this field has been greeted with a scepticism bordering on insult for daring to point out that the use of metaphors might inject an element of fictionality into economists`arguments. Preposterously, Menyhárt (2010) in her comments on McCloskey's reasoning went so far as to argue her rejection of it on the grounds that "the aims of metaphors in rhetoric and in poetry are completely different", since "literary metaphors want neither to persuade nor to predict, just to decorate" (p. 26), a notion which rather spectacularly misses the point of the use of metaphors: The metaphor, by replacing the name of the item it refers to with the name of one which shares some characteristics of the former but is sufficiently different from it to put a slant on its contextual interpretation, is used in literary texts or anywhere else as a device to entice its addressee into sharing this interpretation and as such is a tool of rhetoricity (cf. Lakoff and Johnsen, 2003 pp. 140-142).

Menyhárt's evaluation of McCloskey's venture into epistemological doubt, though, has considerable merit, as it elucidates the fears which makes some exponents of economic thinking still instinctively raise disciplinary drawbridges against the humanities. There are two extremely interesting points she makes in her assessment of McCloskey's arguments besides her mistaken understanding of metaphors. One is that she concurs with the complaints "about the lack of standards of truth and about leaving out the issue of the pursuit of truth from McCloskey's rhetorical theory of economics” (Menyhárt 2010 p. 23) voiced by McCloskey's critics, without, though, even considering that the notion of truth advocated by those critics might be biased by their own interests in shielding their frameworks of reference from any doubt which might undermine those framework's claim on marketable relevance. The other point is that though she definitely agrees with rhetoric being "a key success factor of everyday business" - "you do not get what you deserve, you get what you negotiate" (ibid. p. 27) -, she does not link rhetorical negotiation to the introduction of the fictional elements characteristic of tactics of persuasion, implying that as long as the negotiation is successful and the negotiated issue thus becomes part of the economic value chain the validity of such elements relationship to reality does not matter to the issues' marketability. Thus, this type of reasoning leads to the conclusion that it is, to quote Menyhárt against herself, "a key success factor of everyday business" (ibid. p. 27) precisely because the semantic effects of economists' selecting, configuring and presenting data are not questioned as to their inherent artificiality.

Menyhárt's misappropriation of the concept of rhetoricity in general and of the metaphor in particular points straight at the dimension of meaning supported by epistemological doubt according to our understanding of literacy. The rhetorical use of metaphors, far from being a natural means of communication in each and every writing culture, is in fact an effect of the use of the alphabetic writing system, as it is one of the means employed by Western civilization to deal with the indeterminacy of the meaning of written words engendered by this system. In contrast to writing systems like the Egyptian hieroglyphs or the Mayan-Aztec script or, to stay nearer our own time, Chinese or Japanese writing (see Jones and Aoki, 1988), the twenty-six letters constituting the alphabet have retained nothing of their original pictorial resemblance to the objects whose names went into the constitution of the phonetic alphabet on 
the strength of their initial phonemes. While this loss of visual referentiality was key to the use of the alphabet as an easy-to-learn communication tool, at the same time, by dint of the abstractness of its notational technique, it established the openness and indeed necessity for interpretative choices in linking the content conveyed by it to its users' experience of reality. The employment of metaphors responds to that necessity, as it replaces the semantic guidance of readers through pictorial elements which are still an essential part of Chinese logography with an operation which is only possible through the use of the phonetic alphabet: The reader's guidance is provided through the tension evoked by replacing the name of one object with that of another, the meaning of which latter is similar enough to mark its connection to the replaced name but is determined by a semantically different context. Turned back onto the economist narrative as explored by McCloskey this means that its metaphorical components are a product of the Western writing system, which by proxy suggests that the content conveyed by such metaphors itself is linked to this system and can accordingly be read as to its preconceptions about reality.

Employing epistemological doubt for tracing such phenomena through humanities-based literacy is not per se restricted to any disciplinary field or subject matter. Yet, some fields offer more footholds for exploring its establishment within them, the field of the economist narrative and with it that of management education being one of them, as the growing research interest in the humanities contribution to it outlined in our first section shows. Operationalizing epistemological doubt by teaching how to read cultural practices critically, though, is a major challenge in this field. As the reactions to McCloskey's work testify to, the type of knowledge produced in and through it implies an inherent claim to factual truth for its research results and their presentation which meets the allegation of rhetoricity with ingrained resentment. 'Real' science, that is science which is methodologically modelled on the natural sciences, is understood to be incompatible with aesthetic categories and techniques, as those are tainted with the suspicion of untruthfulness, which makes our concept of literacy's stipulation that cultural practices of any kind, including economics and management practices, need to be read as artifacts in order to gain agency through them, hard to swallow.

Management students being trained for efficiency sets out that reading is a means to a predefined end the use of which is not of interest in and of itself, as Rhodes (2016) would have it: "This knowledge is violently reduced into the virtually indistinguishable tables of contents of textbooks $\langle\ldots\rangle$. To use those books, to feel compelled to use those books, releases a powerful normalizing and disciplining force on what goes on in the classroom." (p. 367) Thus, management students usually read texts for information to be broken down into bullet points, mostly unaware that those texts are presenting information in a manner which has fictional elements, uses rhetorical devices to persuade the reader of its trustworthiness, is constructed to represent reality in the mode of textuality which has in fact little in common with the way sensual experiences of reality are processed by the human brain and, moreover, is firmly grounded in the historical context it inscribes itself into. Similarly, management students usually do not look for fictional, rhetorical, textual and historical elements in the practical reality of management, ignoring, for instance, that the tools they are taught to employ are not just neutral instruments but through their respective characteristics influence the way they are used, since such "tools have affordances that shape the way that actors frame problems but can also enable actors to advance their own interests in that problem" (Jarzabkowski and Kaplan, 2014 p. 539).

To respond to this challenge with a systematic operationalization of epistemological doubt in teaching management students, we have developed a framework we termed Critical Management Literacy (CML, cf. Landfester and Metelmann, 2020). It follows the lines laid out by Nesteruk's (2012) arguing for a "blending model" of management education on the 
strength of "bringing the practice of liberal education to the pedagogies of business" (p. 115). There are several different ways of achieving this, all of which have much to be said for them (cf. Steyaert et al., 2016, part IV "Classrooms" for overview); yet we opted for building our framework on the epistemological expertise at the core of the humanities which has only recently been encoded as crucially relevant to management studies (David et al., 2013). Our main goal to (re)introduce epistemological doubt into management education is encapsuled in the term "critical". We use this term not in the sense of criticism but in that of critique, referring to the process of conscious reflection (from Greek 'krinéin', to separate, sort out), the terms "management literacy" aiming to convey that management is a cultural practice to be read in the manner outlined above.

The framework focusses on four sub-types of literacy: Conceptual Management Literacy, Cultural Literacy, Social Literacy and Interactional Literacy.

- Conceptual Management Literacy is the ability to reflect on management as a concept, that is, as a cultural artefact created in specific institutional and societal contexts and with similarly specific ends, being shaped by underlying norms and values whose relationship to reality needs to be constantly re-examined and re-calibrated.

- Cultural Management Literacy is the ability to understand the way in which those concepts are built, what mechanisms and instruments they rely on, what agendas they are tailored to, and how they are tied to, influenced by and influencing, the culture embedding management practice and theory, up to and including the impact of and dealing with the effects of digitalization on performing management practices.

- Social Management Literacy is the ability to recognize and act on "the relationship between specific instances of situated action and the social world in which the action takes place" (Feldman \& Orlikowski, 2011 p. 1241), in other words, the way in which management is connected with and influences society as a whole and vice versa.

- Interactional Management Literacy is the ability to engage in teamwork, with a focus on collective productivity under the necessity of intercultural and interdisciplinary communication imposed by globalized knowledge transfer.

The common factor linking those four literacies together is the basic axiom that the conceptual, cultural, social and interactional knowledge students acquire by engaging in management studies is shaped by practices which need to be recognized - in our term read - as artifacts rather than being taken for unquestionably true information about reality in order for students to gain agency in dealing with them. On this axiomatic foundation, we present students with reading material on topics like leadership, strategy of entrepreneurship, part of which is taken from texts known or at least structurally close to the corpora they are used to deal with in their discipline like handbooks, political or economic treatises, strategy documents or case studies. This part of the material is paired with literary texts dealing with the same topics rather in the manner of the paired courses advocated by Litton and Wacker (2020). Comparing the different perspectives the texts bring to their subject matter, the different contexts of use they are designed for and accordingly different approach to their implicit addressees, and most importantly the difference between prescriptive and explorative approaches to the respective topics students are challenged to reflect on the way in which their own social, institutional and cultural situatedness influences their response to the concepts they encounter during their studies. 
An example drawn from the master course on "Strategy as cultural practice" (2 ECTS) we co-taught in the Contextual Studies program during the fall term of 2018 at our university may serve to illustrate the issue. In that course, we paired Carl von Clausewitz treatise The War with Heinrich von Kleist's play The Prince of Homburg. Clausewitz' treatise (2002), published in toto only after his death in 1831 but in parts circulating since 1806 and today a seminal part of the strategic management canon, is so explicit about the strategic moves necessary for the Prussian army's military success in the case of war that one of our students very seriously wondered that it should have been allowed to be circulated, since it freely gave away all secrets of Prussian warcraft to the enemy. In the event of warfare - an phenomenon Clausewitz takes for guided by natural laws - the combination of clear objectives, quick perception, rolling planning (versus the aristocratic cabinet mode of planning) and virtue (personal qualities plus esprit de corps) should guarantee the projectability of the fighting conflict. Our students had not difficulty relating to this attitude, since the ideas of predictability, hard work, perseverance and loyalty to the company put forth by Clausewitz are a residual part of traditional management education, just as the prescriptive manner in which they were presented was familiar enough to them as not to be even remarked on, much less questioned.

This, though, changed with their reading Kleist's play against the backdrop of Clausewitz' treatise. Kleist, who knew the parts of the treatise then in circulation, with The Prince of Homburg (1989, original 1809/10) responded to Clausewitz' prescriptive plan-thinking by laying out the problems with their concrete implementation: Prince Frederick, so deeply in love with his superior's niece that he walks in his sleep in the night before the impending battle he is supposed to play a part in, in fact wins that battle by impetuously ignoring said superior's command, a crime in Clausewitz' book, which leads to him being consequently condemned to death by martial court in spite of this victory, a sentence which is in the end only reversed due to the superior's niece loving him back. Normative prescriptions about strategy, Kleist thus lays out, are all very well, but life is infinitely less patient than the paper of a treatise, presenting the humans supposed to adhere to a given order with all sorts of unexpected emotional irritations interfering with proper execution, while at the same time providing for the critical strategic reserve - a prominent category in Clausewitz' treatise, though not, of course, in the way Kleist interpreted it - which ensures a happy ending after all. After much heated discussion, our students finally decided that Kleist probably was far closer to reality than Clausewitz, which led them to at some point even accuse the latter of manipulating his reader rhetorically into believing in the fail-save quality of his stratagems on grounds that would not or at least not always stand the test of their practical implementation.

Literature, as Guillet de Monthoux (2015) put it, "is much more about reality than fiction" (p. 164), since it presents the indeterminacy of meaning inherent to reality much more accurately than prescriptive texts, allowing and even demanding readers to take interpretative choices instead of swallowing information received wholesale. Thus, "reading teaches you to think critically" (Atlas, 2013 p. 138), fostering reflection on conventionalized patterns of interpretation guiding such choices rather than accepting their intrinsic prescriptive force unquestioningly. As Khurana (2007) has pointed out, management students are particularly vulnerable to this force as they expect a sense of practical security from following prescriptions to the letter. The most important characteristic of literacy as we understand it is that it immunizes against this vulnerability by introducing students to a process of re-adjusting their frames of reference and thus their perspective. The literacies taught in the CML framework therefore are designed as "transformative literacies" (Schneidewind, 2013, cf. also Scholz, 2011) in the sense that they induce critical reflection not as a tool for solving especially 
complex problems but as a mind-set which encompasses all intellectual and emotional responses to experience. In this sense, they prime students for understanding and, even more important, constructively participating in the huge transformational shifts currently moving the world towards a future where natural resources are growing scarce, climate change accelerates the dynamics of migration, digital technologies are beginning to blur the boundaries between human and artificial intelligence and globalization challenges cultural hegemonies like, for instance, that of the Western framework of values as installed by the European Enlightenment movement. In other words, literacy is both the precondition and the mode not merely of entering into an individual transformation process, but also of understanding and actively fostering cultural and societal transformation processes (Schneidewind 2018). In that role it is the procurator of a shared body of knowledge about the fact that "producing economic growth does not mean producing democracy. Nor does it mean producing a healthy, engaged, educated population in which opportunities for a good life are available to all social classes" (Nussbaum, 2010 p. 15), as it could and should recognize and help modify the fact that " $<\mathrm{d}>$ emocracies all over the world are undervaluing, and consequently neglecting, skills that we all badly need to keep democracies vital, respectful, and accountable" (ibid. p. 77), skills which, we hold, are grounded in the capacity for epistemological doubt.

\section{Conclusion}

Reinventing management education along the lines of our concept of literacy is certainly not the only conceivable way to pave the road for a new understanding of the academia's added value to society, but, in recognition of the undeniable truth of the Carnegie report's emphatic statement that " $<$ b $>$ usiness has never mattered more" (Colby et al., 2011 p. 1), it may well prove the stepping stone towards an understanding of academic education which leads to a reinvention of universities 'role in globalized society. We hold that this role will rest on the recognition of literacy as crucial to an understanding of academic management education and, indeed, academic education as such where it still subscribes to the Humboldtian vision of the university. Since this vision was based on epistemological doubt, and epistemological doubt, like most, if not all, concepts which make up the closely interwoven fabric of Western cultural practices, owes much of its significance to the alphabetic writing system, such recognition will have to acknowledge the debt it owes to that system in order to gauge the full richness of the possibilities for interpretative choices provided by it.

Literary texts like Dickens' novel already are much aware of this debt, just as they are aware of the danger of cutting interpretative corners by abbreviating complex issues to the point where expectations based on them are in danger of leading those who harbour them into seriously wrong directions. Dickens, for example, showcases this awareness by in his novel's very first sentence explaining that the name of Pip, who is thwarted by his expectations at every turn of the plot, is an abbreviation of Phillip, following this beginning up with a reading scene: Pip, knowing about his father and mother only through the inscriptions on their tombstones, recounts that as a child he was induced by the "shape of letters on my father's" to imagine him as "a square, stout, dark man, with curly black hair", while the shape of the letters on his mother's tombstone leads him to believe her to have been "freckled and sickly" (Dickens, 1965/ 1860-61) p. 35). In the course of the novel bitter experience teaches Pip that applying this simplifying association technique to his interpretation of the reality he encounters constantly leads him astray, until he finally comes back to where he has started out and meets 
Estella again there. Closing on a literary theme, we would in the name of literacy like to identify the humanities resp. the liberal arts with the persona of the formerly cold-hearted Estella, chiming in with the novel's last sentence as written from the perspective of the formerly money-obsessed Pip: "I took her hand in mine, and we went out of the ruined place; $<\ldots>$ and <...> I saw no shadow of another parting from her." (Dickens, 1965 p. 493).

Acknowledgements Open access funding provided by University of St.Gallen.

\section{Compliance with Ethical Standards}

Conflict of Interest On behalf of all authors, the corresponding author states that there is no conflict of interest.

Open Access This article is licensed under a Creative Commons Attribution 4.0 International License, which permits use, sharing, adaptation, distribution and reproduction in any medium or format, as long as you give appropriate credit to the original author(s) and the source, provide a link to the Creative Commons licence, and indicate if changes were made. The images or other third party material in this article are included in the article's Creative Commons licence, unless indicated otherwise in a credit line to the material. If material is not included in the article's Creative Commons licence and your intended use is not permitted by statutory regulation or exceeds the permitted use, you will need to obtain permission directly from the copyright holder. To view a copy of this licence, visit http://creativecommons.org/licenses/by/4.0/.

\section{References}

Arenas, D. 2006. Problematizing and enlarging the notion of humanistic education. In Management Education and Humanities, ed. P. Gagliardi and B. Czarniawska, 113-134. Cheltenham, UK: Edward Elgar.

Atlas, J.L. 2013. The Need to Read. In Shaping the Future of Business Education, ed. G. Hardy and D.L. Everett, 135-141. Basingstoke \& New York: Palgrave Macmillan.

Bazerman, M.H., and D.A. Moore. 2009. Judgment in Managerial Decision Making. Seventh Edition. Danvers/ Mass.: John Wiley \& Sons.

Beigi, M., J. Callahan, and C. Michaelson. 2019. A Critical Plot Twist: Changing Characters and Foreshadowing the Future of Organizational Storytelling. International Journal of Management Reviews 21: 447-465.

Bobko, P. \& Tejeda, M, J.. 2000. Liberal Arts and Management Education: Re-Emphasizing The Link For The twenty-first Century. Journal of the Academy of Business Education: 1-11.

Clausewitz, C., V. 1989. On War. Edited and translated by Howard, M. and Peter Paret. Princeton, NJ: Princeton University Press (Original work published 1831-1832).

Clegg, S., A. Ross-Smith, and A. 2003. Revising the boundaries: Management education and learning in a postpositivist world. Academy of Management Learning \& Education 2 (1): 85-98.

Colby, A., T. Ehrlich, W.M. Sullivan, and J.R. Dolle. 2011. Rethinking undergraduate business education: Liberal learning for the profession. San Francisco: Jossey-Bass and the Carnegie Foundation for the Advancement of Teaching.

Costea, B., and K. Amiridis. 2016. Management education and the humanities: a future together? In The Routledge Companion to Reinventing Management Education, ed. C. Steyaert, T. Beyes, and M. Parker, 523-537. London: Routledge.

Czarniawska, B. 1997. Narrating the Organization: Dramas of Institutional Identity. Chicago: Chicago University Press.

Czarniawska, B., and P. Guillet de Monthoux, eds. 1994. Good Novels, Better Management. Reading: Harwood Academic Publishers.

David, A., Hatchuel A., and R. Laufer, eds. 2013. New Foundations of Management Research: Elements of epistemology for the management sciences. Paris: Presses des Mines.

Dewey, J. 1929. The Quest for Certainty: A Study of the Relation of Knowledge and Action. New York: Minton, Balch \& Co..

Dickens, C. 1965. Great Expectations. London: Penguin (Original work published 1860-1861). 
Donaldson, T.J., and R.E. Freeman, eds. 1994. Business as a Humanity. New York \& Oxford: Oxford University Press.

European Science Foundation (ESF) 2013. Cultural Literacy in Europe today. archives.esf.org/fileadmin/Public documents/Publications/spb48_Cultural_Literacy.pdf. Accessed 15.10.2020.

Figal, G. 1991. Martin Heidegger: Phänomēnologie der Freiheit. Frankfurt/M.: Hain.

Feldman, M., and W. Orlikowski. 2011. Theorizing Practice and Practicing Theory. Organization Practice 22 (5): 1240-1253.

Gadamer, G. 1989. Truth and Method. 2nd ed. London: Sheed and Ward.

Gagliardi, P., and B. Czarniawska, eds. 2006. Management Education and Humanities. Cheltenham, UK \& Northampton, MA, USA: Edward Elgar.

Geertz, C. 1973. Thick Description: Toward an Interpretive Theory of Culture. In The Interpretation of Cultures: Selected Essays. 3-30. New York: Basic Books.

Ghoshal, S. 2005. Bad Management Theories Are Destroying Good Management Practices. Academy of Management Learning \& Education 4 (1): 75-91.

Gottschall, J. 2012. The storytelling animal: How stories make us human. Boston: Houghton Mifflin Harcourt.

Guillet de Monthoux, P. 2015. Art, Philosophy, and Business: turns to speculative realism in European management scholarship. European Management Journal 33 (3): 161-167.

Havelock, E. 1976. Origins of Western Literacy. Ontario: Ontario Institute for Studies in Education.

Hendry, J. 2006. Management education and the humanities: The challenge of post- bureaucracy. In Management Education and Humanities, ed. P. Gagliardi and B. Czarniawska, 21-44. Cheltenham, UK: Edward Elgar.

Hirsch, E.D., Jr. 1987. Cultural literacy: What every American needs to know. Boston: Houghton Mifflin.

Hjort, D., and C. Steyaert. 2004. Narrative and Discoursive Approaches in Entrepreneurship. Cheltenham \& Northampton: Edward Elgar.

Humboldt, W. 1990. Über die innere und äußere Einteilung der höheren wissenschaftlichen Anstalten in Berlin. In Gelegentliche Gedanken über Universitäten. Von Engel, Erhard, Wolf, Fichte, Schleiermacher, Savigny, v. Humboldt, Hegel, ed. Ernst Müller, 273-283. Leipzig: Reclam (Original work published 1809).

Jarzabkowski, P., and S. Kaplan. 2014. Strategy tools-in-use: A Framework for Understanding "Technologies of Rationality" in Practice. Strategic Management Journal 36: 537-558.

John, J. 2003. Dickens's Villains: Melodrama, Character, Popular Culture. Oxford: Oxford University Press.

Jones, E.A., and C. Aoki. 1988. The Processing of Japanese and Kanji Characters. In The Alphabet and the Brain. The Lateralization of Writing, ed. D. De Kerckhove and C.J. Lumsden, 301-319. Heidelberg: Springer.

Kalantzis, M., and B. Cope. 2012. Literacies. Cambridge: Cambridge University Press.

Kant, I. 1784. Beantwortung der Frage: Was ist Aufklärung? Berlinische Monatsschrift 12: 481-494.

Khurana, R. 2007. From Higher Aims to Hired Hands: The Social Transformation of American Business Schools and the Unfulfilled Promise of Management as a Profession. Princeton and Oxford: Princeton University Press.

Kleist, H. 2002. The Prince of Homburg. London: Oberon (Original Prinz Friedrich von Homburg published 1809/1810).

Krugman, P. 1998. Rationales for Rationality. In Rationality in Economics: Alternative perspectives, ed. Ken Dennis, 111-122. New York: Springer Science and Business.

Landfester, U., and J. Metelmann. 2019. Transformative Management Education: The Role of the Humanities and Social Sciences. London: Routledge.

Landfester, U., and J. Metelmann. 2020. De-disciplining humanity: the humanities' case for Critical Management Literacy. Management Learning. https://doi.org/10.1177/1350507620958159.

Lakoff, G., and M. Johnsen. 2003. Metaphors we live by. Chicago: The University of Chicago Press.

Litton, E. \& Wacker, J.. 2020. Paired Courses: Using Liberal Arts to Improve Business Education. Humanistic Management Journal. https://doi.org/10.1007/s41463-020-00090-x..

Lovins, L.H. 2016. Needed: A better story. Humanistic Management Journal 1 (1): 75-90.

Lumsden, C.J. 1988. Gene-Culture-Coevolution: Culture and Biology in Darwinian Perspective. In The Alphabet and the Brain. The Lateralization of Writing, ed. D. De Kerckhove and C.J. Lumsden, 17-42. Heidelberg: Springer.

McCloskey, D. 1983. The Rhetoric of Economics. Journal of Economic Literature 21: 481-571.

McCloskey, D. 1985. The Rhetoric of Economics. Madison: University of Wisconsin Press.

McCloskey, D. 1990. If You're so Smart: The Narrative of Economic Expertise. Chicago \& London: Chicago University Press.

McCloskey, D. 2001. Measurement and Meaning in Economics. Cheltenham and Northampton: Edwards Elder.

Michaelson, C. 2016. A Novel Approach to Business Ethics Education: Exploring How to Live and Work in the twenty-first Century. Academy of Management Learning \& Education 15 (3): 588-606. 
Menyhárt, E. 2010. Rhetoric and Literary Character of Economics. In Second conference on rhetoric and narratives in management research: proceedings, ed. E. Bonet, B. Czarniawska, D. McCloskey, and H.S. Jensen, 15-30. Barcelona: ESADE.

Morgan, G. 1986. Images of Organization. New York/London: Sage.

Nesteruk, J. 2012. Business Teaching, Liberal Learning, and the Moral Transformation of Business Education. Organization Management Journal 9: 114-119.

Nussbaum, M. 2010. Not for Profit: Why Democracy Needs the Humanities. Princeton and Oxford: Princeton University Press.

Oswick, C., and D. Grant. 2015. Re-Imagining Images of Organization: A Conversation With Gareth Morgan. Journal of Management Inquiry 25 (3): 1-6.

Parker, M. 2016. 'This is water': labours of division, institutions and history. In The Routledge companion to reinventing management education, ed. C. Steyaert, T. Beyes, and M. Parker, 497-509. London: Routledge.

Perriton, L., and A. Singh. 2016. Critical Voices in management education in the UK. In The Routledge companion to reinventing management education, ed. C. Steyaert, T. Beyes, and M. Parker, 77-90. London: Routledge.

Pinker, S. 2018. Enlightenment Now: The Case for Reason, Science, Humanism and Progress. New York: Penguin.

Pirson, M. 2020. A Humanistic Narrative for Responsible Management Learning: An Ontological Perspective. Journal of Business Ethics 162: 775-793.

Powell, B. 2012. Writing: Theory and History of the Technology of Civilization. Chichester UK: John Wiley \& Sons.

Rabinow, P. 1986. Representations Are Social Facts: Modernity and Post-Modernity in Anthropology. In Writing Culture. The Poetics and Politics of Ethnography, ed. J. Clifford and G.E. Marcus, 234-261. Berkeley and Los Angeles: University of California Press.

Raffnsøe, S. 2016. Philosophy of the Anthropocene: The Human Turn. Basingstoke: Palgrave Macmillan.

Raffnsøe, S. 2021. The Human Turn in Management Thought. London: Routledge.

Readings, B. 1996. The University in Ruins. Cambridge, MA: Harvard University Press.

Rhodes, C. 2016. 'Permission taking': the humanities and critical pedagogy. In The Routledge companion to reinventing management education, ed. C. Steyaert, T. Beyes, and M. Parker, 361-373. London: Routledge.

Rhodes, C., and A.D. Brown. 2005. Narrative, organizations and research. International Journal of Management Reviews 7 (3): 167-188.

Rorty, R. 1979. Philosophy and The Mirror of Nature. Princeton: Princeton University Press.

Schneidewind, U. 2013. Transformative Literacy: Gesellschaftliche Veränderungsprozesse verstehen und gestalten. GAIA 22 (2): 82-86.

Schneidewind, U. 2018. Die Große Transformation: Eine Einführung in die Kunst gesellschaftlichen Wandels. Frankfurt/Main: Fischer Verlag.

Scholz, R.W. 2011. Environmental Literacy in Science and Society: From Knowledge to Decisions. Cambridge, UK: Cambridge University Press.

Shepard, J.M., M.G. Goldsby, and V.W. Gerde. 1997. Teaching business ethics through literature. Teaching Business Ethics 1: 33-51.

Snow, C.P. 2001. The Two Cultures. London: Cambridge University Press (Original work published 1959).

Statler, M., and P. Salovaana. 2016. Thinking in and of the world: actualizing wisdom and pragmatism in business education? In The Routledge companion to reinventing management education, ed. C. Steyaert, T. Beyes, and M. Parker, 206-220. London: Routledge.

Steyaert, C., T. Beyes, and M. Parker, eds. 2016. The Routledge companion to reinventing management education. London: Routledge.

Thomas, H., M. Lee, L. Thomas, and A. Wilson. 2014. Securing the Future of Management Education: Competitive Destruction or Constructive Innovation? Reflections on the Role, Impact and Future of Management Education: EFMD Perspectives. Vol. 2. Bingley UK: Emerald Publishing Group.

Tsoukas, H. 2005. Complex Knowledge: Studies in Organizational Epistemology. Oxford: Oxford University Press.

Waddock, S., and J.M. Lozano. 2013. Developing More Holistic Management Education: Lessons Learned From Two Programs. Academy of Management Learning \& Education 12 (2): 265-284.

Westerman, J.W., and J.H. Westerman. 2009. Social protest novels in management education: Using Hawk's Nest to enhance stakeholder analysis. Journal of Management Education 33: 659-675.

Younkins, E.W. 2014. Exploring capitalist fiction: Business through literature and film. Lanham, MD: Lexington Books.

Zald, M.N. 1996. More Fragmentation? Unfinished Business in Linking the Social Sciences and the Humanities. Administrative Science Quarterly 41 (2): 251-261. 